\title{
African bats: Conservation in the time of Ebola
}

Jennifer A. Guyton ${ }^{1 *}$ and Cara E. Brook ${ }^{1}$

${ }^{1}$ Department of Ecology and Evolutionary Biology, Princeton University. Princeton, New Jersey. USA. E-mail: jguyton@princeton. edu (JAG)

${ }^{*}$ Corresponding author

\begin{abstract}
Introduction: Bats are among the most poorly studied mammals, despite their diversity and important ecological services. The ongoing Ebola epidemic in western Africa underscores the increasingly recognized role of bats as reservoirs for emerging human diseases. An understanding of the mechanisms supporting pathogen maintenance in bat hosts is essential to informing future public health measures, as well as conservation efforts for wild bat populations. This is crucial in Africa, where the human population is burgeoning, increasing habitat loss and human contact with wildlife.
\end{abstract}

The importance of natural history. The natural history and ecology of bats, especially in Africa, is poorly understood, making responsible management decisions difficult. Metrics for guiding management of pathogens and their host populations, such as critical community size and minimum viable population size, often require more natural history knowledge than we currently have available. We argue that management action without adequate research can lead to counterproductive results. In the past, fear-based management responses such as culling campaigns have counterintuitively increased the prevalence of pathogens in the target host population, as has been observed in the vampire bat-rabies system and the Egyptian fruit bat-Marburg system.

Bat conservation in the time of Ebola. Many of the same anthropogenic stressors that are threatening bat populations, such as habitat loss and hunting, are also likely drivers of zoonotic pathogen emergence. Given this, and given that reducing bat populations can increase rather than decrease pathogen prevalence, we argue that conservation measures for bats should be strengthened in this time of Ebola. We offer a few potential first steps.

Conclusions and Future Directions: We advocate the precautionary principle, and encourage significant and urgent increases in natural history studies, education, and conservation measures for African bats.

Key words: bat conservation, Chiroptera, culling, Ebola, natural history, zoonotic pathogens

\section{Introduction}

Most emerging infectious diseases of humans are zoonotic in origin (Taylor et al. 2001), and the ongoing Ebola crisis highlights the increasingly-publicized role of bats as important reservoirs for zoonotic disease (Leroy et al. 2014). Though not the most represented mammalian order among zoonotic hosts (Woolhouse and Gowtage-Sequiera 2005), bats appear to host more viruses per species than rodent reservoirs for zoonotic disease (Luis et al. 2013), and bat-borne zoonoses are notable for their striking human pathogenicity (Dobson 2005). Indeed, bats are now the acknowledged reservoir hosts for rabies and related lyssaviruses, Hendra and Nipah henipaviruses, Marburg virus, and SARS- and MERS- coronaviruses, all known zoonotic agents causing severe pathology in humans (Calisher et al. 2006; Memish et al. 2013; Amman et al. 2014). Additionally, bats are a likely, though as yet unconfirmed, reservoir for Ebola virus (Olival and Hayman 2014). 
Despite this incriminating evidence, bats also play a critical role in ecosystems on all continents except Antarctica. Bats provide a wide range of ecosystem services, from seed dispersal and forest regeneration to control of invertebrate agricultural pests. Their loss in any system is likely to have cascading consequences for ecosystem health and human wellbeing (Kunz et al. 2011). In fact, one study estimated that bat control of agricultural pests could be worth up to $\$ 53$ billion per year in the US alone (Boyles et al. 2011).

Bat populations across the globe are threatened by anthropogenic stressors to ecosystems, including habitat loss, roost disturbance, hunting, and climate change (Mickleburgh et al. 2002 and 2009, Welbergen et al. 2008). As of 2002, almost a quarter of known bat species were globally threatened (Mickleburgh et al. 2002), and threats to bat populations are only increasing as the human population continues to grow. Efforts to conserve bats are non-existent in most of Africa (Racey 2013), despite the major challenges that arise from widespread human consumption of fruit bats (Pteropodidae; Mickleburgh et al. 2009). In fact, pteropodids, which serve as reservoirs for the majority of known bat-borne emerging zoonoses, are significantly more threatened than other bat families (Schipper et al. 2008). Habitat loss and hunting of pteropodids could play a major role in spillover of zoonotic disease, underscoring the importance of understanding and mitigating these threats.

Careful management will be necessary to promote peaceful coexistence of humans and wildlife, including bats, into the future. This will be especially challenging in Africa, where bathuman contact rates are high and where at least three bat-borne zoonotic viruses have emerged in the last half-century (Ebola and Marburg filoviruses and Duvenhage lyssavirus; Gear et al. 1975; Pourrut et al. 2005; Paweska et al. 2006). Challenges will only escalate as human populations continue to increase; the African continent is projected to double its existing human population and take the lead in world population growth by 2050 (UN Department of Economic and Social Affairs 2013, Haub and Kaneda 2014; Zinkina and Korotayev 2014). The continent is expected to harbor around $40 \%$ of the world's human population by the end of this century (You et al. 2014).

The most deadly of the bat-borne diseases that have arisen on the African continent are the Ebola filoviruses, which caused nearly 1,600 documented human deaths prior to 2013 (Pourrut et al. 2005; Leroy et al. 2009; Albariño et al. 2013; Olival and Hayman 2014) and have so far resulted in over 8,600 (as of late January 2015, CDC documented human deaths during the current outbreak). Although the current crisis is driven by human-to-human transmission and has not been confirmed to be linked to bats, the ongoing outbreak has raised questions among local populations in multiple countries and in the popular media about control of possible reservoir hosts (e. g. Lee 2014; Konan 2014; Odemwingie and Tsan 2014), in this case, several fruit bat species such as Hypsignathus monstrosus, Epomops franqueti, and Myonycteris torquata (Leroy et al. 2005). Culling in the face of zoonotic disease is not unprecedented among bats. It has been used since the 1960's in an attempt to control rabies virus in Peru (Arellano-Sota 1988), has been advocated as a method for controlling Hendra virus among flying foxes in Australia (Martin and Mcllwee 2002), and was used in 2008 in an effort to combat Marburg virus in Uganda (Amman et al. 2014). At present, localized culling and eviction efforts are occurring in Africa as a response to the Ebola outbreak in Cameroon (J. Fahr, pers. comm. November 20, 2014) and Nigeria (The Rainbow 2014). However, as we will discuss, bat culling for pathogen control has proven ineffective, and, in fact, has counterintuitively increased rabies prevalence in vampire bats and Marburg virus prevalence in Egyptian fruit bats.

We contend that dramatic management action against zoonotic disease reservoirs, such as a culling campaign, should be avoided in the absence of knowledge-based predictive models. However, our present understanding of the natural history, population dynamics, and disease dynamics of bat species, especially in Africa, is gravely inadequate for generating the models 
necessary to guide management action. Though we are beginning to unravel physiological mechanisms permitting bats to host pathogens at the individual level (Baker 2013; O'Shea et al.2014; Brook and Dobson 2015), an understanding of the mechanisms enabling pathogen persistence at the population level remains elusive. Management action such as culling could have unforeseen and counterintuitive effects on pathogen dynamics, while also placing understudied African bat populations at risk of extinction. Thus, we strongly advocate the precautionary principle: our tenuous grasp on many aspects of bat ecology and natural history could lead to a counterintuitive increase in infection rates or extinction of ecologically important species if management action is attempted. Instead, we recommend: 1 ) improving our understanding of bats and their pathogens via detailed natural history studies, 2) promoting understanding and caution via educational campaigns, and 3) mitigating human-bat contact through habitat conservation measures for bats.

\section{The Importance of Natural History}

The practice and esteem of natural history, defined as "the observation and description of the natural world, with the study of organisms and their linkages to the environment being central", has dramatically declined over the past 40 years (Tewksbury et al. 2014). However, knowledge gleaned through natural history studies of pathogen reservoir species (Figure 1) -in particular, population size and distribution, frequency of intra- and interspecific interaction, movement dynamics, and life history traits - will be critical to parameterizing predictive models for enzootic
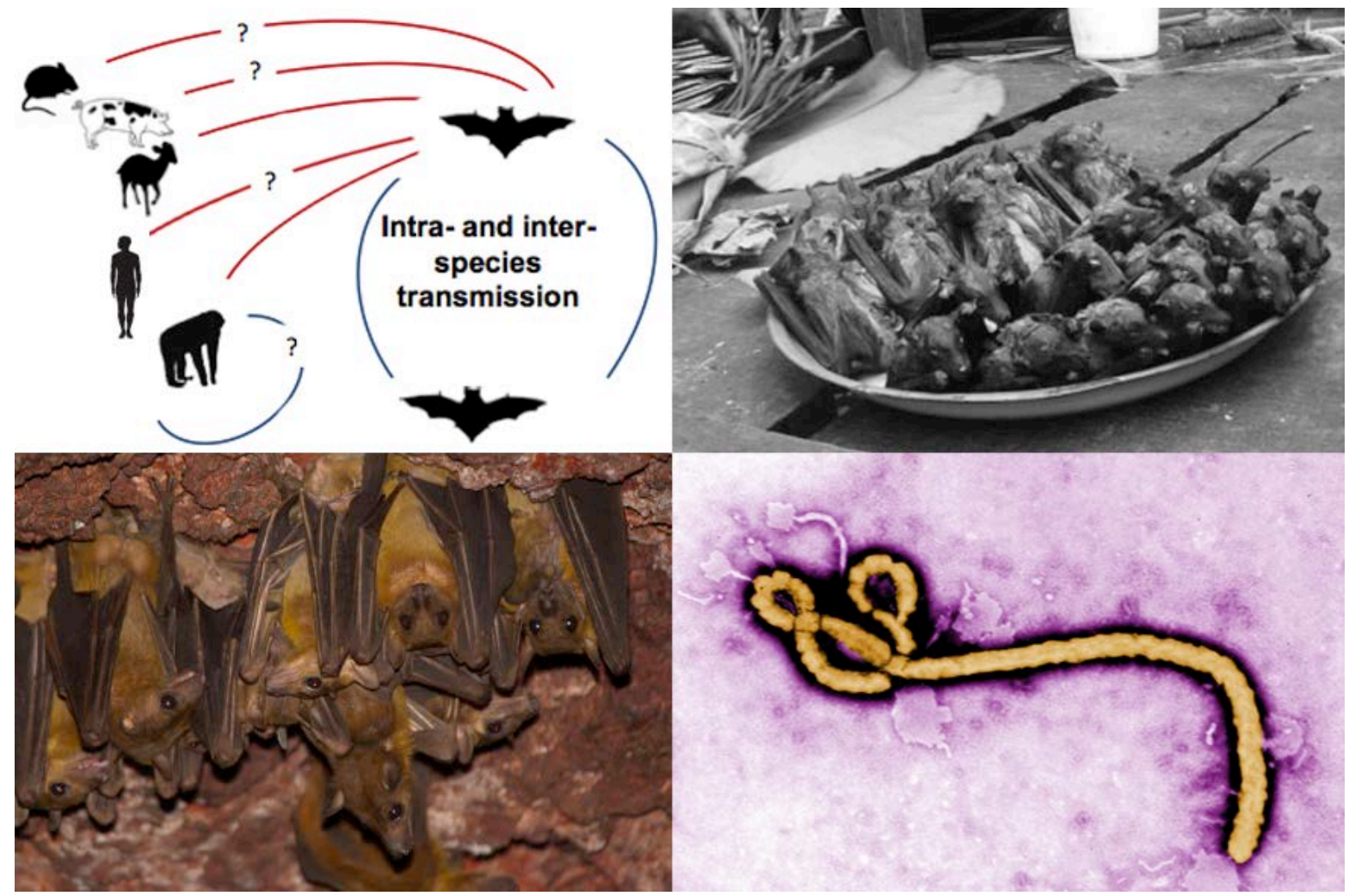

Figure 1. Natural history information is critical for making management decisions. Clockwise from top left: 1) The natural history and behavior that drives intra- and inter-species transmission of Ebola is not well understood (figure adapted from Olival and Hayman 2014). 2) the bushmeat trade is widespread on the African continent. Here, a number of straw-colored fruit bats (Eidolon helvum) and one hammer-headed fruit bat (Hypsignathus monstrosus), in both of which Ebola antibodies have been detected, for sale as bushmeat in Kisangani, Democratic Republic of the Congo. Knowledge of the human-wildlife interface is crucial (Photo by Guy-Crispin Gembu Tungaluna, Mickleburgh et al. 2009). 3) The Ebola filovirus. We must learn more about pathogen dynamics and what behavioral and ecological traits drive intra- and inter-species pathogen transmission (Photo source: Wikimedia Commons). 4) Egyptian fruit bats (Rousettus aegyptiacus) roosting in a cave in West Africa. Our knowledge of colony and population sizes and dynamics is poor for many species (Photo by Piotr Naskrecki). 
pathogen dynamics in the reservoir host and to making assessments of potential risk for zoonotic epidemics.

Though recognition of bats' roles in zoonotic disease is growing, information supporting the basic ecology of bat reservoirs, especially in Africa, is lacking (Monadjem et al. 2010a). In the case of Ebola, many critical natural history questions for possible reservoir hosts are still outstanding. How many bats, and of which species, are infected? How do the various fruit bat species transmit the pathogen to one another? Are males and females and bats of all age classes equally likely to transmit the pathogen? Why do outbreaks occur sporadically? Are there seasonal behavioral or physiological changes important to viral shedding among hosts? Without answers to these basic questions, our capacity for intervention is limited.

Management action in the face of a pathogen outbreak often involves changing the population dynamics of a pathogen or its host, either by reducing numbers, inoculating host individuals, or moving host individuals. Consequently, two of the most important metrics for making management decisions regarding pathogens and their hosts are critical community size and minimum viable population size.

\section{Critical community size}

The crucial role of host population size in the transmission and maintenance of pathogens is a core principle in disease dynamics (Kermack and McKendrick 1927). Typically, a pathogen will invade a naïve, or uninfected, host population when the pathogen's "basic reproduction number" is greater than one (i. e., $R_{0}>1$ ), meaning that an average infected individual passes the pathogen to more than one conspecific. This allows the pathogen to reproduce infections at a rate sufficient to maintain transmission. The required number of hosts for invasion and persistence of a disease in the population varies based on the transmissibility of the pathogen and the rate of recovery from infection in the host. During early work on human measles in UK cities, Bartlett (1957) coined the term "critical community size" (CCS), which refers to the threshold host population size necessary for long-term maintenance of a given pathogen. (Note that because the concept of CCS was devised for human systems, "community" in this context does not refer to the ecological concept of multiple associated species; rather, it refers to all individuals, associated in space and time, of all species susceptible to infection by the pathogen in question). CCS is not well characterized in most wildlife populations and its applicability has been debated. Certain pathogens, chiefly those transmitted in a frequencydependent manner, including vector-borne pathogens but also certain behaviorally-mediated directly-transmitted pathogens (i.e. bite-transmitted lyssaviruses), will not be limited by host CCS (Lloyd-Smith et al. 2005). The relevance of CCS has only recently come under discussion in relation to zoonotic pathogens in bat reservoirs (Peel et al. 2012, 2013). By definition, "reservoir species" enable pathogens to persist; thus, understanding the mechanisms supporting pathogen persistence in bat populations will be critical to efforts to mitigate human public health risk for zoonoses.

In theory, a pathogen can be controlled and a host population downgraded from "reservoir" status by bringing the host population size below the CCS. In order to consider such measures, detailed knowledge of both pathogen dynamics and host population dynamics, locally and within a metapopulation context, is essential. However, such complementary knowledge of both host and pathogen dynamics is difficult to obtain. In a literature review examining correlates of viral richness in bat hosts, Turmelle and Olival (2009) identified only 33 of approximately 1,200 extant bat species globally for which both an estimate of host viral richness and host population structure, indicative of some awareness of host population dynamics, were available. 


\section{Minimum viable population size}

The smaller a population is, the more susceptible it is to extinction by chance events and/or by deterministic anti-regulating forces (Allee effect; Lidicker 2010). The Minimum Viable Population Size concept was formalized by Shaffer (1981), who defined a "minimum viable population" (MVP) of a given species in a given habitat as any population size supporting a $99 \%$ chance of surviving at least 1,000 years into the future. To estimate MVP in Yellowstone grizzly bears, he then developed a model that simulates population trajectories by incorporating demographic and environmental stochasticity to generate extinction probabilities for any given starting population size (Shaffer 1983; Shaffer and Samson 1985). This was the first true population viability analysis (PVA) using mathematical modeling to assess extinction risk, and to determine MVP in a given population (Beissinger and McCullough 2002). Since its origins, the MVP theory has grown in complexity and PVA has evolved into precise modeling efforts, with recognition that species survival is contextspecific and that there is no rule of thumb for a viable minimum population size (Traill et al. 2007; Flather et al. 2011a, b). Though PVA in its various iterations has been applied to numerous organisms and systems the world over, the concept has never been formally applied to bats. The simulations at the core of PVA require accurate, long-term census data and knowledge of effective population size, or the number of individuals that contribute to reproduction. These basic natural history data are lacking for most bat species, especially on the vastly understudied African continent.

\section{Estimating population size in bats}

CCS and MVP are closely related concepts that have the same threshold: $R_{0}=1$. For a pathogen to persist, a host community must be large enough (the "critical community size") that each individual passes the pathogen to at least one other on average. For a population of hosts to persist, it must be large enough (the "minimum viable population") that each individual is at least on average able to replace itself over its lifetime, and the population must exceed in numbers any minimum threshold density that may be imposed by Allee effects (Lidicker 2010).

The calculation of CCS and MVP are critical for making management decisions for controlling a pathogen or for conserving a threatened species, and they rely on some knowledge of the population size and dynamics for the species in question. However, bat population sizes are inherently difficult to estimate because of bats' high mobility, nocturnal habits, and roosting sites that are difficult to locate and access. Traditional methods such as mark-recapture are rarely successful in estimating bat population sizes, due to low recapture rates and failure to meet the method's assumptions of equal survival and capture probability for marked and unmarked individuals (Kunz et al. 2009; Schorr et al. 2014). Changes in population size can be especially difficult to detect in bats, particularly among species that do not roost in large colonies: one recent study showed that more than 25,000 individuals would need to be captured and marked each year to detect a $33 \%$ decline in the annual survival of solitary, migratory tree-roosting bats in North America (Schorr et al. 2014). In fruit bats, local abundance can be highly variable based on fruit and flower availability, and many species are migratory (Happold and Happold 2013), further complicating assessments of population change. In fact, since seasonal fluctuations are known to play a role in pathogen dynamics (Altizer et al. 2006), seasonal fluxes in range and in colony size may be more important, though potentially even more challenging to quantify, than overall population size or average colony size (Turmelle and Olival 2009).

Much work remains to be done, and modern technologies are advancing our ability to address these challenges. For example, for colony-roosting species, the power of mark-recapture studies is improved by using pit-tag readers installed at the entry and exit points of roosts to increase 
the recapture rate. For cave-roosting bats, colony size can be extrapolated to population size using models based on cave density (Peuchmaille et al. 2009), which can be readily mapped using GIS. Recently, microsatellite analysis using fecal DNA has been adopted to estimate local colony size from genetic diversity in a given sample (Peuchmaille and Petit 2007). It is imperative that we take advantage of cutting-edge technologies to improve our natural history knowledge of bats and their pathogens.

\section{Distribution and connectivity of bat populations}

Recent work has shown that the shape of a host's geographical distribution, in addition to its population size, can have profound implications for pathogen dynamics (Figure 2). Maganga et al. (2014) showed that bats with a larger and more fragmented geographic range were more likely to harbor greater viral richness. This may occur because of cross-species pathogen transmission at the edges of a host species' distribution (Maganga et al.2014), or be due to the greater genetic structure present in a fragmented population, with moderate levels of genetic structure leading to the highest viral richness (Turmelle and Olival 2009). Greater viral richness and genetic diversity promote evolutionary flexibility in these pathogens, resulting in a higher likelihood that one of those viruses has the capacity to spill over into human populations (Morse 1993). Conversely, however, high host population connectivity can have important implications for the spread of a single pathogen.

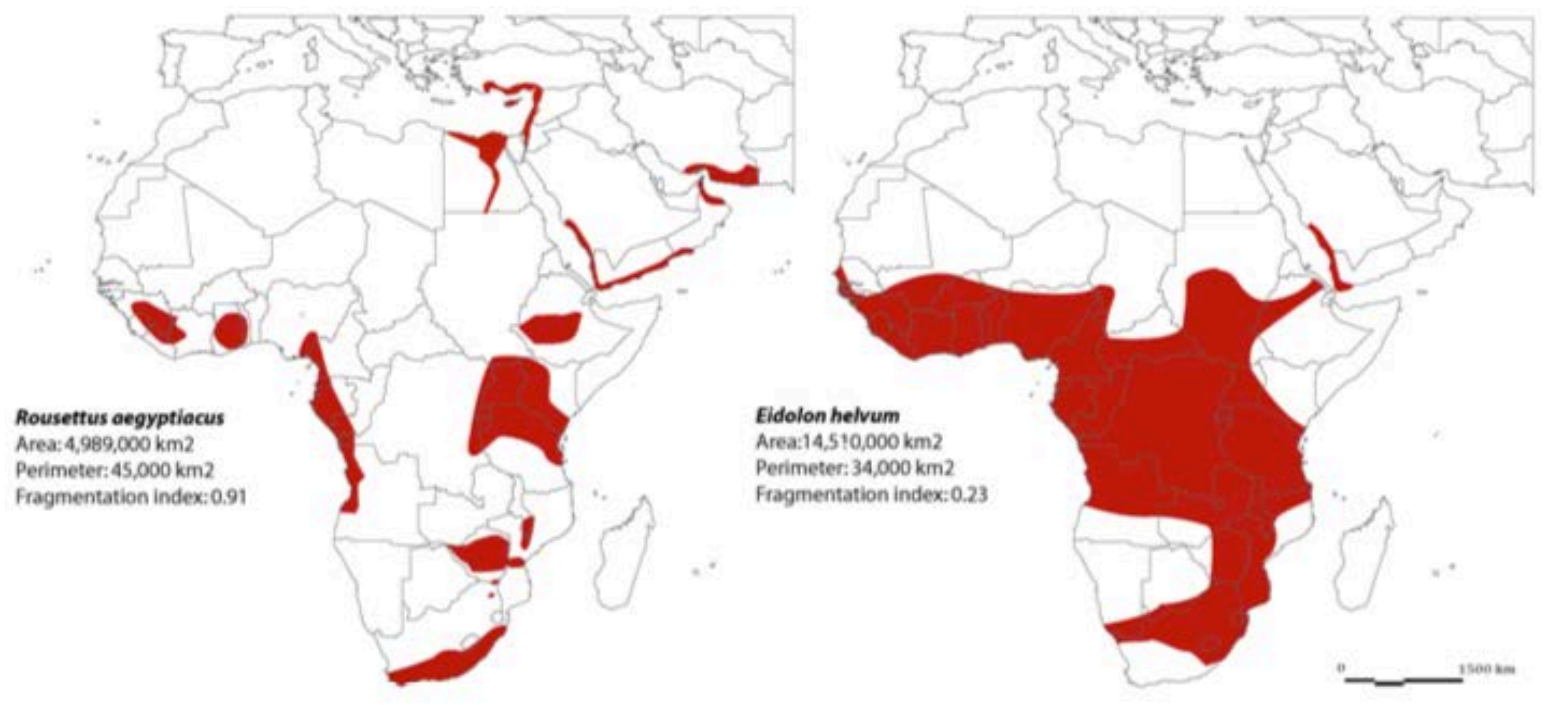

Figure 2. Range maps for Rousettus aegyptiacus (left) and Eidolon helvum (right), in both of which Ebola antibodies have been detected. Fragmented species ranges in Africa may be range gaps or knowledge gaps. If the latter, they must be filled (Maps from Maganga et al. 2014).

The unusually well-studied straw-colored fruit bat (Eidolon helvum), for example, exhibits an extraordinary genetic panmixia across its vast continental range (Peel et al. 2013). No genetic isolation is evident among African populations separated by more than 4,500 km, making E. helvum the largest ever documented panmictic unit of any mammal. This high connectivity among many millions of individuals could have serious implications for the transmission and maintenance of emerging zoonotic pathogens (Peel et al. 2013). With a migratory route that can span more than 2,500 km (Richter and Cumming 2008), E. helvum could be an effective cross-continental African viral emissary that also comes into contact with human populations via urban roost sites and bushmeat consumption (Hayman et al. 2008). 
Though not linked directly to the current Ebola epidemic, nor implicated as an important Ebola reservoir, E. helvum has demonstrated seropositivity for Ebola (Hayman et al. 2010) and is known to share foraging and roost sites with Epomops franqueti (Jones 1972), a likely reservoir for the virus (Leroy 2005). Bat species with overlapping geographic ranges are known to share viruses between species extensively (Luis et al. 2013). Because many fruit bats and some microbats migrate in response to local rainfall patterns and hence food availability (Happold and Happold 2013), some bats may be sequentially sympatric with multiple other species, possibly increasing the extent of viral mixing. Pathogen control measures are thus further complicated by possible alternative reservoirs. Even if one species is extirpated, a pathogen can persist in a sympatric species. Ebola antibodies and/or RNA have been detected in at least nine fruit bat species (Leroy 2005; Hayman et al. 2008; Pourrut et al. 2009; Hayman et al. 2012; Reed 2012) and one microbat species (Pourrut et al. 2009; Table 1) with combined ranges spanning most of sub-Saharan Africa (Figure 3). Consequently, efforts to control a pathogen with significant cross-species behavior (such as Ebola) via population control of one or even multiple hosts would approach impossibility.

These recent insights into the effects of host distribution on pathogen transmission underscore the importance of conducting abundance and diversity surveys in poorly known geographic areas. Gaps are apparent in the distributions of many African bat species (Monadjem et al. 2010a). However, because many areas of Africa lack survey data for bats, discriminating knowledge gaps from true species absence is challenging. Additionally, many distribution maps currently rely on surveys conducted 30-40 years ago or more (Happold and Happold 2013), although anthropogenic influence has surely led to more recent changes. In particular, habitats are becoming increasingly fragmented as deforestation progresses, which may have substantial effects on population range and connectivity and hence on viral richness and spread. It is crucial that our natural history knowledge keeps pace with these changes.

\section{Lessons from the past: applying population knowledge to interventions}

In the past, culling has been used or proposed as a primary management tool for controlling pathogen prevalence in wild mammalian host species. Culling operations rely on two assumptions: 1) $R_{0}$ for a pathogen increases with the host population size $(N)$, and, in turn, fadeout of the pathogen becomes more likely as the population shrinks; and 2 ) culling directly affects $N$ in a predictably negative way.

Table 1. African bat species in which evidence of Ebola infection has been found, and the location of the study. The geographic ranges of these species have been given in Figure 3.

\begin{tabular}{|c|c|c|c|}
\hline Family & Species & Location & References \\
\hline Pteropodidae & Eidolon helvum & Ghana & Hayman et al. 2010; Hayman et al. 2012 \\
\hline Pteropodidae & Epomops franqueti & Gabon/Republic of Congo; Ghana & $\begin{array}{l}\text { Leroy 2005; Pourrut et al. 2007; Pourrut et al. } \\
\text { 2009; Hayman et al. } 2012\end{array}$ \\
\hline Pteropodidae & Epomophorus gambianus & Ghana & Hayman et al. 2012 \\
\hline Pteropodidae & Epomophorus labiatus & Sudan, Uganda & Reed 2012 \\
\hline Pteropodidae & Hypsignathus monstrosus & Gabon/Republic of Congo; Ghana & $\begin{array}{l}\text { Leroy 2005; Pourrut et al. 2009; Hayman et al. } \\
\qquad 2012\end{array}$ \\
\hline Pteropodidae & Micropteropus pusillus & Gabon/Republic of Congo & Pourrut et al. 2009 \\
\hline Pteropodidae & Myonycteris torquata & Gabon/Republic of Congo & $\begin{array}{l}\text { Leroy et al. 2005; Pourrut et al. 2007; Pourrut et } \\
\qquad \text { al. } 2009\end{array}$ \\
\hline Pteropodidae & Nanonycteris veldkampii & Ghana & Hayman et al. 2012 \\
\hline Pteropodidae & Rousettus aegyptiacus & Gabon/Republic of Congo & Pourrut et al. 2009 \\
\hline Molossidae & $\begin{array}{l}\text { Mops condylurus (Tadarida } \\
\text { condylura) }\end{array}$ & Gabon/Republic of Congo & Pourrut et al. 2009 \\
\hline
\end{tabular}


Under these assumptions, $\mathrm{N}$ and $R_{0}$ are not affected by reactionary processes such as immigration of susceptible individuals, compensatory reproduction (Choisy and Rohani 2006), or confounding evolutionary factors (Bolzoni and De Leo 2013). Conceivably, if the CCS for the pathogen in question is larger than the MVP for the host, managers could maintain bat populations while eradicating disease. This, however, would require a much more detailed understanding of population size, CCS, and MVP in bats than we currently possess.

Thus far, efforts to control zoonotic events by reducing reservoir populations below CCS have had unpredictable results (Donnelly et al. 2003; Streicker et al. 2012; Blackwood et al. 2013). The consequences of attempting pathogen management without adequate knowledge are especially evident in the cases of vampire bat control in Peru and Egyptian fruit bat control in Uganda. Management authorities have attempted culling as a means of controlling the transmission of rabies virus from vampire bats (Desmodus rotundus) to livestock and humans. Managers have employed "vampiricide," a paste applied to the fur of captured vampire bats, which kills conspecifics as they groom treated individuals (Arellano-Sota 1988). Vampire bat culling efforts are based on assumptions of density-dependent viral transmission; the bats must reach a critical community size before the virus can gain a foothold and become persistent, or "enzootic", in the population. However, Streicker et al. (2012) found that rabies virus prevalence was unrelated to colony size, and was actually higher in bat colonies that were subjected to culling. In fact, rabies appears to be transmitted in a frequency-dependent manner based on behavioral biting patterns of bat hosts. Since frequency-dependent transmission is independent of population size, culling is ineffective. In addition, vampire bat culling practices appear to have variable demographic effects: adults, which have already gained immunity due to exposure, may be disproportionately culled, which could increase $R_{0}$ by opening niche space for susceptible juveniles to proliferate (Streicker et al. 2012).

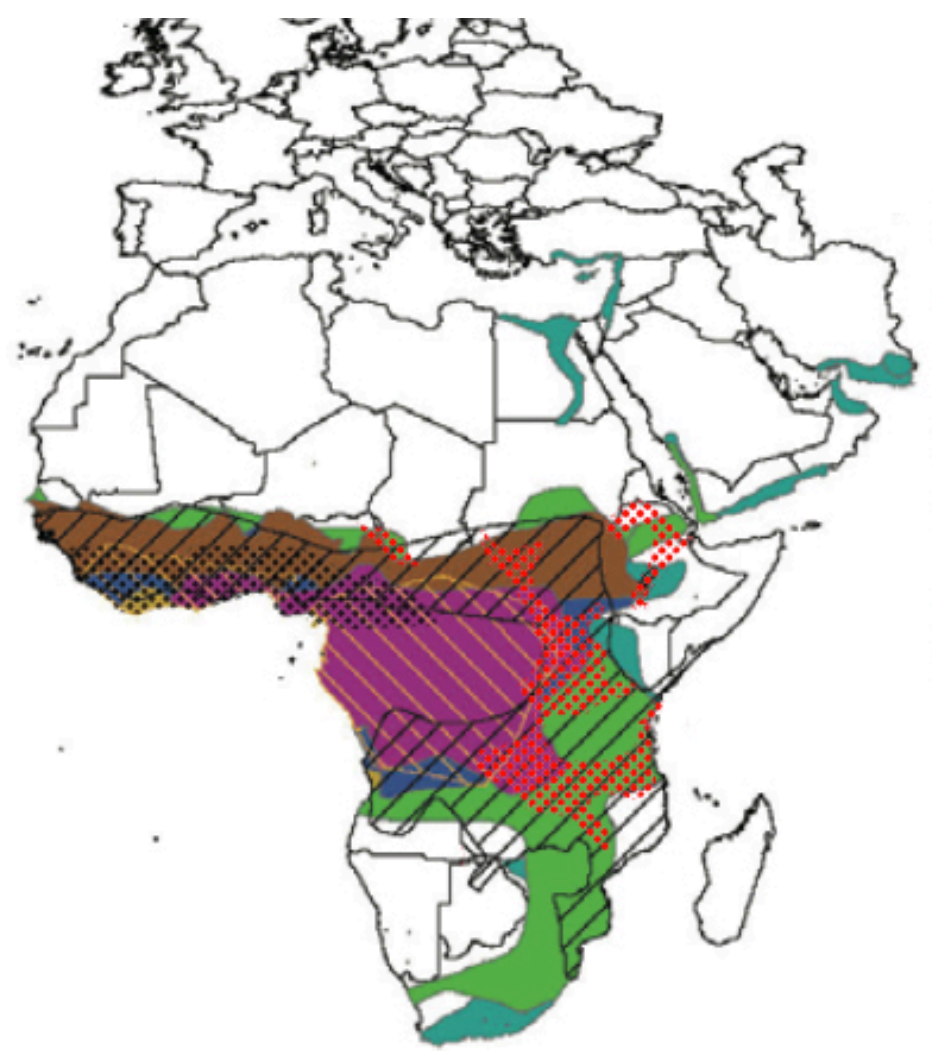

Eidolon helvum

Epomophorus gambianus

Epomophorus labiatus

Epomops franqueti

Hypsignathus monstrosus

Micropteropus pusillus

Myonycteris torquata

Nanonycteris veldkampii

Rousettus aegyptiacus

Mops condylurus

Figure 3. Range maps of the 10 African species of bat in which Ebola antibodies and/or DNA have been detected, showing their highly sympatric and cross-continental distributions (adapted from Olival and Hayman 2014). 
In Uganda, six human cases (two fatal) of Marburg Hemorrhagic Fever (MHF) occurred in 2007 and 2008. All cases were linked to Kitaka Mine or a nearby cave, each location containing 40,000-100,000 Egyptian fruit bats (Rousettus aegyptiacus). These bats were confirmed to be Marburg reservoirs. In response, miners at Kitaka exterminated the fruit bat colony by blocking off the mine entrance with fishing nets, in which the bats became entangled. The entrances were then sealed. In 2012, a larger outbreak of MHF occurred in Ibanda, about $20 \mathrm{~km}$ from Kitaka Mine, resulting in 15 human cases of the disease. Amman et al. (2014) found that R. aegyptiacus had recolonized the mine, with a new colony that was 1 to $5 \%$ of the original size. Phylogenetic analysis showed that Marburg virus strains in the new colony were nearly identical to those isolated from patients in Ibanda, making the Kitaka bats a likely source of the outbreak. Tests indicated that Marburg virus prevalence in the new fruit bat colony was significantly higher than before the culling efforts, with an increase from $5.1 \%$ in $2007 / 2008$ to $13.3 \%$ in 2012 . Moreover, this prevalence was significantly higher than in unculled Egyptian fruit bat populations in Uganda (2.5\%) and Gabon (4.8\%). It is possible that after the colony was culled, Kitaka was reinhabited by a pool of susceptible individuals, leading to higher transmission rates and thus a greater risk of spillover (Amman et al. 2014).

Unintended consequences of culling such as these described for vampire bats and Egyptian fruit bats may not be unique. In a rare case where sufficient data supports efforts to model the effects of bat culling on pathogen prevalence, a similar result is predicted: recent models demonstrate the inefficacy of culling infected individuals as a control method for White Nose Syndrome in North American bats (Hallam and McCracken 2010). To reduce $R_{0}$ for any pathogen, it is not strictly necessary to reduce the number of individuals, but to reduce the rate of transmission among those individuals (Carter et al. 2009). This transmission is often dependent on host density but can be independent of host population size in the case of pathogens transmitted via frequency-dependent mechanisms. Modeling efforts suggest that, due to the highly communal nature of the bat species affected by WNS, even a greatly reduced population would maintain dispersal between roost sites and high contact between individuals, thus still allowing for high transmission rates in hibernacula and maternity colonies (Hallam and McCracken 2010).

Other efforts to model culling effects demonstrate how, in cases of superinfection, or the coexistence of multiple viral strains within a given host, culling could impart a strong selective pressure for establishment of the less virulent strain (Bolzoni and De Leo 2013). Typically, viral strains that are less virulent in hosts will have fewer negative impacts on host fitness. Thus, they result in less frequent host mortality and are able to persist at lower population sizes, reducing the CCS and making their eradication more difficult. As many viral pathogens that show mild virulence in bats exhibit extreme virulence in other mammalian hosts (O'Shea et al. 2014; Brook and Dobson in press), such culling practices have important implications for zoonotic risk: culling may support the persistence, and sometimes higher prevalence, of pathogens within bat reservoirs, eventually enabling spillover to humans (Bolzoni and De Leo 2013).

As a side effect, culling may also endanger non-target species. Vampire bat culling threatens the population viability of a sympatric, endemic bat species, Dekeyser's nectar bat (Lonchophylla dekeyseri), which shares roosts with vampire bats. The nectar bats experience high mortality via incidental poisoning and roost destruction intended to kill vampire bats (Aguiar et al. 2010). Such unintended consequences for non-target species could be a particularly important concern in bats, since multi-species roosting and feeding groups are common. For example, during a campaign to eradicate Egyptian fruit bats (R. aegyptiacus) in Israel during the 1950s in an effort to reduce damage to fruit crops, approximately $90 \%$ of insectivorous bats, which roosted in the same caves, were lost as unintended casualties. This resulted in an explosion in the population of noctuid moths, causing substantial crop damage (Makin and Mendelssohn 1985). 
Thus, culling operations can have a number of counterintuitive effects on pathogen prevalence and species dynamics. Any such management action consequently requires the use of PVA, the quantification of CCS, knowledge of host and pathogen dynamics, and knowledge of the natural history of potentially impacted, non-target species to carefully model the impacts of intervention. Although predicting thresholds for pathogen persistence is difficult in most wildlife species (LloydSmith et al. 2005), it is especially challenging in bats because of our poor understanding of bat ecology and natural history, which is particularly lacking among African bats. Hence, even if the fine balance between CCS and MVP were attempted, culling may worsen our disease crisis and lead to the endangerment or extinction of target and non-target bat species.

\section{Looking to the future - Mozambique as case study}

A study of bat communities by J. Guyton in Mozambique, where data on Chiroptera are scarce, is currently in progress. Before 2010, the most recent species inventory was compiled in 1976 (Smithers and Lobão Tello 1976), and it largely ignored the northern half of the country (Monadjem et al. 2010b). Though an inventory was published in 2010 (Monadjem et al. 2010a), many areas of Mozambique remain under-surveyed, and some of the northern parts continue to lack data entirely (Van Cakenberghe 2013). Before this survey, Gorongosa National Park was only surveyed for small mammals twice, and with limited scope, since the beginning of the civil war in 1977: two localities were surveyed as part of a countrywide effort in 2010 (Monadjem et al. 2010b), and a rapid assessment was conducted on Mount Gorongosa in 2011, with only opportunistic records of bats.

Working in this dramatically understudied country is rapidly yielding much new information on the distribution and natural history of African bats. As one example, Lander's horseshoe bat (Rhinolophus landeri) is commonly cited in the literature as roosting in colonies no larger than a dozen individuals in southern Africa (Smithers 1983; Taylor 2000; Monadjem et al. 2010a). However, an R. landeri colony of over 200 individuals has been documented in central Mozambique that is stable both within and between years. This colony is in a defunct well near the park's headquarters (Guyton, in prep). Thus, some assessments of bat colony and total population size may be off by an order of magnitude or more due to geographical gaps in knowledge, posing serious challenges for any effort to model pathogen dynamics among bat hosts or extinction estimates for threatened populations.

Additionally, the fruit bat Epomophorus crypturus was not recorded in this region since recorded by Smithers and Lobão Tello (1976). It was feared that this species may have been extirpated due to direct persecution for its role as a crop pest as well as widespread conversion of its forest habitat. However, several individuals of E. crypturus were captured in the park buffer zone earlier this year (Guyton, unpublished data). Additionally, dramatic morphological differences have been noted among bats that have been placed in the same Epomophorus species, indicating that there may be more species diversity within that genus than currently thought (Figure 4; Guyton, unpublished data). Natural history observations such as these are important for assessments of human disease risk in the region, especially when concerning fruit bat species, which harbor the bulk of bat-borne zoonotic diseases. Knowledge gaps such as those existing in Mozambique will be crucial to fill as we strive to preempt zoonotic public health crises. Placing emphasis on shifting funding toward natural history studies while training local biologists to tackle such questions can help to fill these gaps.

\section{Bat conservation in the time of Ebola}

Presumably, bat populations have served as reservoirs for pathogens highly virulent to other mammalian hosts since their origins. Indeed, bats demonstrate deep phylogenetic relationships with lyssaviruses (Badrane 2001), filoviruses (Taylor et al. 2010), paramyxoviruses (Drexler et al. 2012), coronaviruses (Cui et al. 2007), hepadnaviruses (Drexler et al. 2013), hepaciviruses (Quan 
2012), influenza A virus (Tong et al. 2012), and simplexviruses (Sasaki 2014), as well as with certain non-viral pathogens including malarial protozoa (Schaer et al. 2013), trypanosomes (Barnabe et al. 2003; Ramírez et al. 2014) and Bartonella spp. bacteria (Kosoy et al. 2010). In spite of this ancient history, however, most high profile bat-borne zoonotic events have occurred within the last two decades (Dobson 2005). This begs the question: what is different about today's ecosystems that has led to so many recent spillover events?

\section{Anthropogenic pressures and pathogen spillover}

Various lines of evidence suggest that anthropogenic disturbance of bat populations and their habitats is likely responsible for the recent upsurge in bat-borne emerging diseases. Most batrelated zoonotic events have stemmed from Old World fruit bat reservoirs, which have experienced hunting-attributed declines of up to a quarter of their original population sizes over the past fifty years (Mickleburgh et al.2009). Rates of fruit bat harvest appear to be unsustainable globally (Epstein et al. 2009; Divljan 2011; Kamins et al. 2011), often with the greatest harvest effort concentrated on reproductive female bats (Mickleburgh 2002; Brook unpublished data). Additionally, the reduction of bat numbers by hunting can, like culling, have counterintuitive effects on disease dynamics. This is especially true since human hunters target adult individuals that may have already gained immunity to the pathogen (Mickleburgh 2002), leaving niche space for susceptible juveniles (Streicker et al. 2012). In addition, hunting appears to be linked to spillover events: there is evidence of intensive hunting of relevant bat populations in the regions of zoonotic emergence for
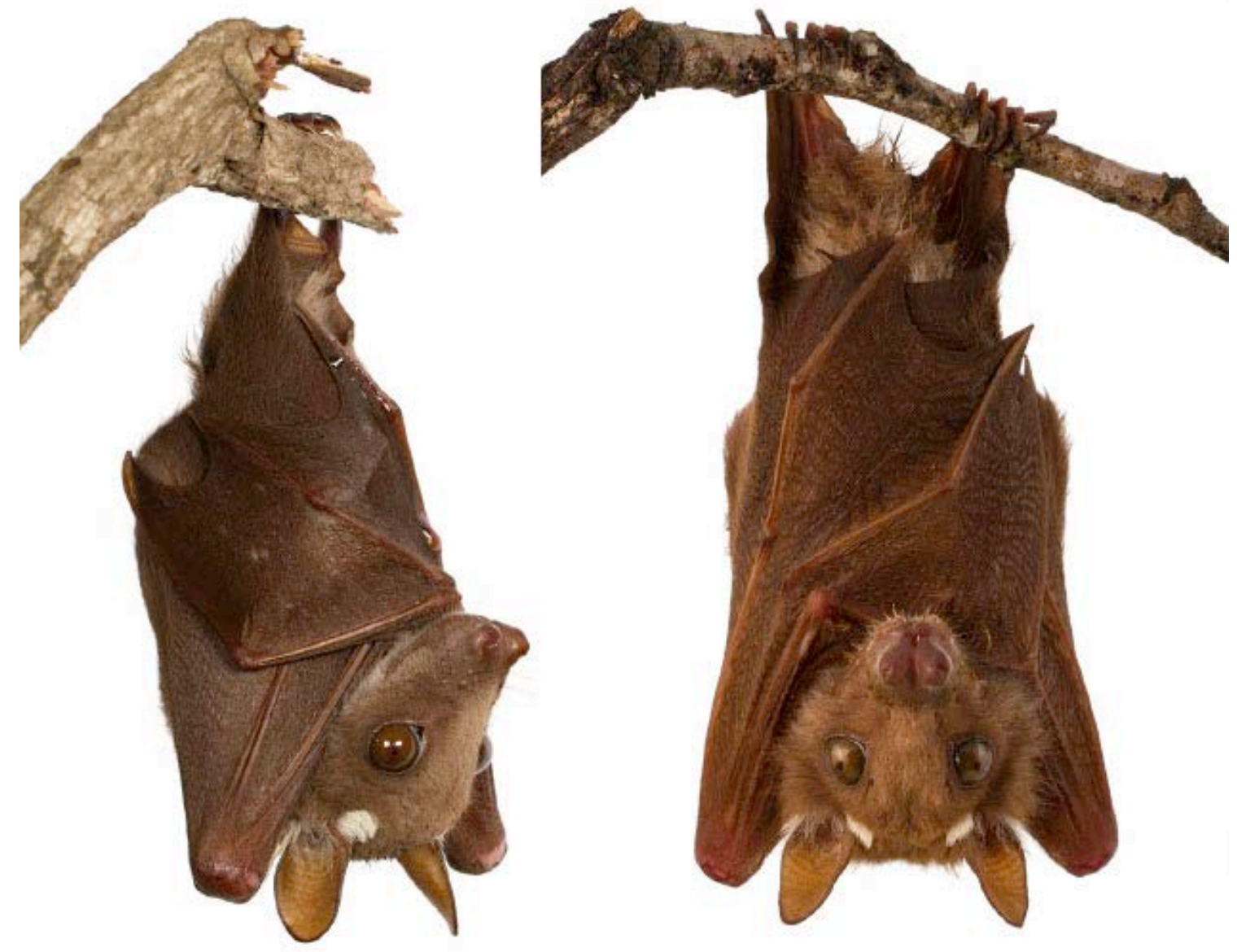

Figure 4. Two species of Epomophorus from Gorongosa National Park, Mozambique. Left: An unusual individual that keys out to E. wahlbergi. Right: E. crypturus (Photos by Piotr Naskrecki). 
Hendra virus (Divljan 2006), Nipah virus (Epstein et al. 2009), SARS-CoV (Mickleburgh et al. 2009), and Ebola virus (Leroy et al. 2009). Ebola outbreaks have been directly linked to contact with bushmeat, with cases arising from handling of primate carcasses (Formenty et al. 1999; Leroy et al. 2004), as well as, potentially, hunting and consumption of fruit bats (Leroy et al. 2009). Elevated contact with animals will always make hunters potential conduits for pathogens, even in the absence of other indirect effects of hunting on pathogen prevalence.

Human encroachment into natural habitats may also play a role in recent spillover events. In the case of Nipah virus, agricultural intensification may have heightened contact between bat reservoirs and secondary pig hosts. This may have allowed for repeated reintroductions of Nipah virus into swine populations, from which the virus was subsequently transferred to the human population (Pulliam et al. 2012). In the case of Hendra virus, anthropogenic habitat fragmentation is posited to have resulted in a loss of immunity in isolated flying fox populations, thus leading to epidemic spikes in flying fox infection upon pathogen introduction via a rare migratory individual. These epidemics, in turn, are thought to drive emergence into secondary horse hosts and eventual spillover into humans (Plowright et al. 2011).

Additionally, habitat loss and resource provisioning can go hand-in-hand to create a push-pull dynamic that draws potential reservoir species into human settlements. For example, a boom in the Latin American livestock industry has provided a ballooning food source for vampire bats, thus drawing the reservoir into closer contact with humans and exacerbating zoonotic disease (Streicker et al. 2012). In Australia, ornamental plants in urban and suburban environments provide pteropodids with year-round access to fruiting and flowering trees (Parry-Jones and Augee 2001; Markus and Hall 2004; Plowright et al. 2011), attracting bats into areas of high human population density and increasing the risk of zoonotic pathogen transmission through indirect contact. Indeed, in Mozambique, pteropodid bats of the genus Epomophorus are more frequently captured in human communities than in natural habitats, as the former provide access to high concentrations of cultivated fruit (Guyton unpublished data). It is crucial to understand how the behavioral drivers of this phenomenon in bats could be exploited to improve conservation measures and relieve the pressures that are driving bats into situations that put humans at risk of spillover.

\section{Bat conservation and community education}

The above evidence indicates that anthropogenic pressure may be contributing to increased emergence of bat-borne zoonotic pathogens. Increased conservation measures, such as protection of remaining forested habitat, habitat restoration, and hunting restrictions can help relieve this pressure and reduce the potential for spillover. The establishment of a zoonotic pathogen in human populations able to maintain independent transmission is thought to usually follow multiple, dead-end spillover events from wildlife populations-a phenomenon termed "viral chatter" (Wolfe et al. 2005). Reducing contact frequency between humans and wildlife hosts would reduce the intensity of this viral chatter, thus mitigating the likelihood of a zoonotic pathogen adapting (either behaviorally or genetically) to sustain human-to-human transmission, as has occurred with Nipah virus in Bangladesh (Luby et al. 2009) and, recently, with Ebola in West Africa (Leroy et al. 2014).

Creative solutions can be devised to reduce human contact with bats without resorting to population control measures. For example, exclusion netting over crops can reduce damage by fruit bats while simultaneously reducing provisions that attract bats to human communities (Fleming and Robinson 1987). In an effort to minimize wildlife-human contact and combat Ebola, the governments of Guinea (Bausch and Schwarz 2014) and Sierra Leone (Ansumana et al. 2014) 
have recently banned all harvesting and sale of bushmeat. These laws, however, are poorly enforced, and the sale of bushmeat continues in the region (Gyasiwaa 2014; UN Office for Coordination of Humanitarian Affairs 2014). This is an unsurprisingly common phenomenon, given that deeply entrenched cultural practices can be difficult to change, and people often rely on bushmeat for nutrients that are difficult to attain elsewhere (Golden et al. 2011).

Although quashing the bushmeat trade thoroughly and immediately is unrealistic, efforts can be made to shift human behavior and educate the public in a way that reduces the risk of zoonotic transmission. One potential compromise, if seasonal dynamics are found to be important in viral infection prevalence among bats, might be to impose a hunting season accompanied by awareness campaigns. Additionally, discouraging people from hunting or scavenging notable pathogen reservoirs, such as particular fruit bat species and great apes, could reduce exposure to the riskiest situations. Encouraging safer slaughter and handling practices of wildlife and domestic stock may also help. Ultimately, however, for human safety and for the preservation of biodiversity, human development efforts should aim to provide communities with safe, sustainable sources of animal protein.

Finally, our burgeoning zoonotic disease crisis has yielded an influx of North American and European biologists spearheading bat-related research projects in Africa, projects that need to be accompanied by more earnest educational outreach efforts. Within the U. S., Lubee Bat Conservancy, founded in Gainseville, Florida in 1989, offers a quality model for bat education and conservation that we believe has the potential for application in the developing world. At Lubee, captive breeding for fruit bat conservation takes place side-by-side with active research efforts, educational outreach, and tourism. Researchers sincere in their desires to educate Africans about bats should look to centers like Lubee as a model for how to carry out public health and disease-related science in conjunction with outreach promoting bat conservation in the developing world.

\section{Conclusions and future directions}

While ongoing research into the internal structure of emerging pathogens such as Ebola virus (Gire et al. 2014) and efforts to develop treatments (Mupapa et al. 1999) and vaccines (FaustherBovendo et al. 2012) are of undeniable importance, quarantine of infected humans and mitigation of spillover from wild reservoir populations may be the most effective public health measures in controlling epidemics in regions, like Africa, with limited medical services (Leroy et al. 2014). Thus, we should aim to understand bats and their pathogens sufficiently to know at which point to intervene in the cycle of transmission. Our current knowledge of the basic natural history of bats, especially in Africa, is woefully inadequate to attempt any accurate prediction of the impact of management interventions on the population dynamics of wild bats and the pathogens they host. However, as bat-borne zoonoses are increasing in frequency and severity (Leroy et al. 2014), it is paramount that we undertake natural history studies informing models of pathogen and host population dynamics and their responses to proposed interventions.

Bat natural history research was once limited by how difficult bats are to observe, but modern technology is changing that. In particular, much-needed assessments of population size and connectivity for bat species across the globe are becoming increasingly possible with the help of modern molecular and remote sensing technologies. Population assessments for bats will be particularly important in understudied regions, such as Africa, where human-bat contact rates are high and risk for zoonotic emergence is substantial. Such assessments will be important for efforts to explain both pathogen persistence in reservoir communities of varying sizes and structures, as well as to assess the vulnerability of reservoir species to extinction risk in the face of proposed interventions, such as culling. 
Previous research indicates that bushmeat hunting, anthropogenic land conversion, and human encroachment into natural habitats have played key roles in the heightened emergence of bat-borne zoonotic diseases during the past half-century. Though we are still disentangling the mechanisms producing the majority of spillover events, evidence is sufficient to merit our strong support of the precautionary principle: handicapped as we are by a dearth of basic ecological knowledge, drastic population-level interventions could have dire consequences for at-risk bats globally, as well as unintended, sometimes counterproductive, consequences for pathogen control. Rather than risk exacerbating our present health crisis and initiating a conservation dilemma with hasty intervention measures, we instead advocate for detailed natural history studies combined with serious efforts to minimize human-bat contact through education and conservation campaigns. In the time of cholera epidemics, Gabriel García Márquez wrote (1988), "wisdom comes to us when it can no longer do any good." In the time of Ebola, let's seek that wisdom while it may still be of use.

\section{Acknowledgements}

We thank R. M. Pringle, A. P. Dobson, P. Naskrecki, T. C. Coverdale, and the members of the Pringle Lab at Princeton University for their helpful comments on this manuscript. This work was supported in part by two Princeton University graduate fellowships and two National Science Foundation Graduate Research Fellowships to J. A. G. and C. E. B, and support from the Gregory C. Carr Foundation and a National Geographic Young Explorers Grant to J. A. G.

\section{Resumen}

Introducción: Los murciélagos son algunos de los mamíferos más pobremente estudiados, a pesar de su diversidad y los importantes servicios ecológicos que prestan. La epidemia actual de Ébola en el occidente de África subraya el papel cada vez más reconocido de los murciélagos como reservorios de enfermedades humanas emergentes. La comprensión de los mecanismos que permitan el mantenimiento de patógenos en los murciélagos como hospederos es fundamental para diseñar las futuras medidas en salud pública, así como los esfuerzos de conservación de las poblaciones de murciélagos silvestres. Esto es crucial en África, donde la población humana está creciendo y aumentando la pérdida de hábitat además del contacto humano con la vida silvestre.

La importancia de la historia natural: La historia natural y la ecología de los murciélagos, especialmente en África, son poco conocidas, por lo que la toma de decisiones de gestión por parte de los responsables es difícil. Las medidas para la gestión de los patógenos y sus reservorios, como el tamaño crítico de la comunidad y el mínimo viable de población, a menudo requieren más conocimientos de la historia natural que el existente actualmente. Sostenemos que una acción de gestión sin una investigación adecuada puede conducir a resultados contraproducentes. En el pasado, las respuestas de gestión basados en el miedo, como el de las campañas de sacrificio de ejemplares han aumentado la prevalencia de patógenos en la población destino principalmente, como se ha observado en el sistema de murciélago-vampiro de la rabia y el sistema fruto del palo-Marburg egipcio.

Conservación de murciélagos en los tiempos del Ébola: Muchos de los mismos factores de estrés antropogénicos que amenazan las poblaciones de murciélagos, como la pérdida de hábitat y la caza, son también las causas probables de la aparición de patógenos zoonóticos. Ante esto y dado que la reducción de las poblaciones de murciélagos puede aumentar la prevalencia de patógenos en lugar de disminuirla, sostenemos que las medidas de conservación de los murciélagos deben fortalecerse en esta época del Ébola. Se presentan los primeros pasos potenciales.

Clonclusiones y direcciones futuras: Evocamos al principio de precaución, y animan a los aumentos significativos y urgentes en estudios de historia natural, la educación, y las medidas de conservación de los murciélagos africanos.

Palabras clave: : Chiroptera, conservación de murciélagos, Ébola, historia natural, sacrificio, zoonosis patógena 


\section{Literature cited}

AguiaR, L. M. S., D. Brito, ANd R. B. Machado. 2010. Do current vampire bat (Desmodus rotundus) population control practices pose a threat to Dekeyser's nectar bat's (Lonchophylla dekeyseri) long-term persistence in the Cerrado? Acta Chiropterologica 12:275-282.

Albariño, C. G., T. Shoemaker, M. L. Khristova, J. F. Wamala, J. J. Muyembe, S. Balinandi, A. Tumusimme, S. Campbell, D. Cannon, A. Gibbons, E. Bergeron, B. Bird, K. Dodd, C. Spiropoulou, B. R. Erickson, L. Guerrero, B. Knust, S. T. Nichol, P. E. Roluin, AND U. StröHer. 2013. Genomic analysis of filoviruses associated with four viral hemorrhagic fever outbreaks in Uganda and the Democratic Republic of the Congo in 2012. Virology 442:97-100.

Altizer S., A. Dobson, P. Hosseinı, P. Hudson, M. Pascual, and P. Rohani. 2006. Seasonality and the dynamics of infectious diseases. Ecology Letters 9:467-484.

Amman, B. R., L. Nyakarahuka, A. K. McElroy, K. A. Dodd, T. K. Sealy, A. J. Schuh, T. R. Shoemaker, S. Balinandi, P. Atimnedi, W. Kaboyo, S. T. Nichol, AND J. S. Towner. 2014. Marburgvirus resurgence in Kitaka mine bat population after extermination attempts, Uganda. Emerging Infectious Diseases 20:1761-1764.

Ansumana, R., J. Bonwitt, D. A. Stenger, and K. H. Jacobsen. 2014. Ebola in Sierra Leone: a call for action. The Lancet 384(9940). doi: 10.1016/S0140-6736(14)61119-3.

Arellano-Sota, C. 1988. Vampire bat-transmitted rabies in cattle. Review of Infectious Diseases 10 (Supplement 4): S707-S709.

Badrane, H., AND N. ToRdo. 2001. Host switching in lyssavirus history from the Chiroptera to the Carnivora orders. Journal of Virology 75: 8096-8104. doi:10.1128/JVI.75.17.8096.

BakeR, M. L., T. Schountz, AND L. F. WANG. 2013. Antiviral immune responses of bats: a review. Zoonoses and Public Health 60:104-116.

Barnabe, C., S. Brisse, and M. Tibayrenc. 2003. Phylogenetic diversity of bat trypanosomes of subgenus Schizotrypanum based on multilocus enzyme electrophoresis, random amplified polymorphic DNA, and cytochrome b nucleotide sequence analyses. Infection, Genetics and Evolution 2:201-208.

Bartlett, M. S. 1957. Measles periodicity and community size. Journal of the Royal Statistical Society, Series A 120:48-70.

Bausch, D. G., AND L. Schwarz. 2014. Outbreak of ebola virus disease in Guinea: where ecology meets economy. PLoS Neglected Tropical Diseases 8: e3056.

Beissinger, S. R., ANd D. R. McCullough. 2002. Population viability analysis. University of Chicago Press. Chicago, USA.

Blackwood, J. C., D. G. Streicker, S. Altizer, and P. Rohani. 2013. Resolving the roles of immunity, pathogenesis, and immigration for rabies persistence in vampire bats. Proceedings of the National Academy of Sciences 110:20837-20842.

Bolzoni, L., AND G. A. De Leo. 2013. Unexpected consequences of culling on the eradication of wildlife diseases: The role of virulence evolution. The American Naturalist 181:301-313.

Boyles, J. G., P. M. CRyan, G. F. McCracken, ANd T. H. Kunz. 2011. Economic Importance of Bats in Agriculture. Science 332:41-42.

Brook, C. E., AND A. P. Dobson. 2015. Bats as 'special' reservoirs for emerging zoonotic pathogens. Trends in Microbiology. doi:10.1016/j.tim.2014.12.004 <http://dx.doi.org/10.1016/j.tim.2014.12.004>.

Calisher, C. H., J. E. Childs, H. E. Field, K. V. Holmes, and T. Schountz. 2006. Bats: important reservoir hosts of emerging viruses. Clinical Microbiology Reviews 19:531-545.

Carter, S. P., S. S. Roy, D. P. Cowan, G. Massei, G. C. Smith, W. JI, S. Rossi, R. Woodroffe, G. J. Wilson, and R. J. Delahay. 2009. Options for the control of disease Il: targeting hosts. Pp. 121-146 in Management of Disease in Wild Mammals (Delahay, R. J., G. C. Smith, and M. R. Hitchings, eds.). Springer Publishing. Tokyo, Japan.

Center for Disease Control (CDC). “2014 Ebola Outbreak in West Africa - Case Counts”. January 21, 2015. <http://www.cdc.gov/vhf/ebola/outbreaks/2014-west-africa/case-counts.html> 
Choisy, M., And P. Rohanı. 2006. Harvesting can increase severity of wildlife disease epidemics. Proceedings of the Royal Society B 273: 2025-2034.

Cui J., N. Han, D. Streicker, G. LI, X. Tang, Z. Shi, Z. Hu, G. Zhao, A. Fontanet, Y. Guan, L. Wang, G. Jones, H.E. Field, P. Daszak, And S. Zhang. 2007. Evolutionary relationships between bat coronaviruses and their hosts. Emerging Infectious Diseases 13:1526-1532.

Divluan, A., K. Parry-Jones, and G. M. Wardle. 2006. Age determination in the grey-headed flying fox. Journal of Wildlife Management 70:607-611.

Divluan, A., K. Parry-Jones, and P. Eby. 2011. Deaths and injuries to Grey-headed Flying-foxes, Pteropus poliocephalus shot at an orchard near Sydney, New South Wales. Australian Zoology 35:698-710.

Dobson, A. P. 2005. What links bats to emerging infectious diseases? Science 310:628-629.

Donnelly, C. A, R. Woodroffe, D. R. Cox, J. Bourne, G. Gettinby, A. M. Le Fevre, J. P. Mclnerney, and W. I. MorRIson. 2003. Impact of localized badger culling on tuberculosis incidence in British cattle. Nature 426:834-837.

Drexler, J. F., V. M. Corman, M. A. Müller, G. D. Maganga, P. Vallo, T. Binger, F. Gloza-Rausch, V. M. Cottontail, A. Rasche, S. Yordanov, A. Seebens, M. Knörnschild, J. Schmidt-Chanasit, A. Stöcker, A. J. Borges Carneiro, and S. Erbar. 2012. Bats host major mammalian paramyxoviruses. Nature Communications 3(796):1-12.

Drexler, J. F., A. Geipel, A. König, V. M. Corman, D. van Riel, L. M. Leijten, C. M. Bremer, A. Rasche, V. M. Cottontall, G. D. Maganga, M. Chlegel, M. A. Müller, A. Adam, S. M. Klose, A. J. Borges Carneiro, A. Stöcker, C. R. Franke, F. Gloza-Rausch, J. Geyer, A. Annan, Y. Adu-Sarkodie, S. Oppong, T. Binger, P. Vallo, M. Tschapka, R. G. Ulrich, W. H. Gerlich, E. Leroy, T. Kuiken, D. Glebe, and C. Drosten. 2013. Bats carry pathogenic hepadnaviruses antigenically related to hepatitis $B$ virus and capable of infecting human hepatocytes. Proceedings of the National Academy of Sciences 110:16151-16156.

Epstein, J. H., K. J. Olival, J. R. C. Pulliam, C. Smith, J. Westrum, T. Hughes, A. P. Dobson, A. Zubaid, S. A. Rahman, M. M. Basir, H. E. Field, and P. Daszak. 2009. Pteropus vampyrus, a hunted migratory species with a multinational home-range and a need for regional management. Journal of Applied Ecology 46:991-1002.

Fausther-Bovendo, H., S. Mulangu, and N. J. Sullivan. 2012. Ebola virus vaccines for humans and apes. Current Opinion in Virology 2:324-329.

Flather, C. H., G. D. Hayward, S. R. Beissinger, and P. A. Stephens. 2011 a. Minimum viable populations: is there a 'magic number' for conservation practitioners? Trends in Ecology and Evolution 26:307316.

Flather, C. H., G. D. Hayward, S. R. Beissinger, and P. A. Stephens. 2011b. A general target for MVPs: unsupported and unnecessary. Trends in Ecology and Evolution 26:620-622.

Fleming, P. J., AND D. Robinson. 1987. Flying fox (Chiroptera: Pteropodidae) on the north coast of New South Wales damage to stone fruit crops and control methods. Australian Mammalogy 10:143-145.

Formenty, P., C. Hatz, B. Le Guenno, P. Rogenmoser, and A. Widmer. 1999. Human infection due to Ebola virus, Subtype Cote d'Ivoire: Clinical and biological presentation. Journal of Infectious Diseases 179:48-53.

Gear, J. S., G. A. Cassel, A. J. Gear, B. Trappler, L. Clausen, A. M. Meyers, M. C. Kew, T. H. Bothwell, R. Sher, G. B. Miller, J. Schneider, H. J. Koornhof, E. D. Gomperts, M. Isaäcson, and J. H. Gear. 1975. Outbreake of Marburg virus disease in Johannesburg. British Medical Journal 4(5995):489-493.

Gire, S. K., A. Goba, K. G. Andersen, R. S. G. Sealfon, D .J. Park, L. Кanneh, S. Јalloh, M. Момoh, M. Fullah, G. Dudas, S. Wohl, L. M. Moses, N. L. Yozwiak, S. Winnicki, C. B. Matranga, C. M. Malboeuf, J. Qu, A. D. Gladden, S. F. Schaffner, X. Yang, P. Jiang, M. Nekoul, A. Colubri, M. R. Coomber, M. Fonnie, A. Molgbol, M. Gbakie, F. K. Kamara, V. Tucker, E. Konuwa, S. Saffa, J. Sellu, A. Azziz Jalloh, A. Kovoma, J. Koninga, I. Mustapha, K. Kargbo, M. Foday, M. Yillah, F. Kanneh, W. Robert, J. L .B. Massally, S. B. Chapman, J. Bochicchio, C. Murphy, C. Nusbaum, S. Young, B. W. Birren, D. S. Grant, J. S. Scheiffelin, 
E. S. Lander, C. Happl, S. M. Gevao, A. Gnirke, A. Rambaut, R. F. Garry, S. H. Khan, and P. C. Sabeti. 2014. Genomic surveillance elucidates Ebola virus origin and transmission during the 2014 outbreak. Science 345(6202):1369-1372.

Golden, C. D., L. C. H. Fernald, J. S. Brashares, B. J. Rodolph-Rasolofoniaina, and C. Kremen. 2011. Benefits of wildlife consumption to child nutrition in a biodiversity hotspot. Proceedings of the National Academy of Sciences 108:19653-19656.

GyasıwaA, A. 2014. "Bat-eating galore at Boben despite Ebola outbreak". Adom Online. < http://ghana-news. adomonline.com/news/2014/October-30th/bat-eating-galore-at-boben-despite-ebola-outbreak. php>

Hallam, T. G., and G. F. McCracken. 2 010. Management of the Panzootic White-Nose Syndrome through Culling of Bats. Conservation Biology 25:189-194.

Happold, M., AND D. C. D. Happold (eds.). 2013. Mammals of Africa. Volume IV: Hedgehogs, Shrews and Bats. Bloomsbury Publishing. London, United Kingdom.

Haub, C. and T. Kaneda. 2014. World Population Data Sheet. Population Reference Bureau. Retrieved 2 Oct 2014. <http://www.prb.org/pdf14/2014-world-population-data-sheet_eng.pdf>

Hayman, D. T. S., A. R. Fooks, D. Horton, R. Suu-Ire, A. C. Breed, A. A. Cunningham, and J. L. N. Wood. 2008. Antibodies against Lagos Bat Virus in Megachiroptera from West Africa. Emerging Infectious Diseases 14:926-928.

Hayman, D. T. S., P. Emmerich, M. Yu, L. Wang, R. Suu-Ire, A. R. Fooks, A. A. Cunningham, and J. L. N. Wood. 2010. Long-term survival of an urban fruit bat seropositive for Ebola and Lagos Bat Viruses. PLoS One DOI: 10.1371/journal.pone.0011978.

Hayman, D. T. S., M. Yu, G. Crameri, L. Wang, R. Suu-Ire, J. L. N. Wood, and A. A. Cunningham. 2012. Ebola virus antibodies in fruit bats, Ghana, West Africa. Emerging Infectious Diseases 18:1207-1209.

Hayman, D. T. S., R. McCrea, O. Restif, R. Suu-Ire, A. R. Fooks, J. L. N. Wood, A. A. Cunningham, And J. M. Rowcliffe. 2012. Demography of straw-colored fruit bats in Ghana. Journal of Mammalogy 93:1393-1404.

Jones, C. 1972. Comparative ecology of three pteropodid bats in Rio Muni, West Africa. Journal of Zoology, London 167:353-370.

Kamins, A. O., O. Restif, Y. Ntiamoa-Baidu, R. Suu-Ire, D. T. S. Hayman, A. A. Cunningham, J. L. N. Wood, and J. M. RowcLIFFE. 2011. Uncovering the fruit bat bushmeat commodity chain and the true extent of fruit bat hunting in Ghana, West Africa. Biological Conservation 144:3000-3008.

Kermack, W. O. And A. G. McKendrick. 1927. A contribution to the mathematical theory of epidemics. Proceedings of the Royal Society London, Series A 115:700-721.

Konan, M. 2014. "Menace de fièvre Ebola: Des experts proposent une operation d'envergure contre les chauves-souris du Plateau". L'Infodrome (Côte d'Ivoire). <http://www.linfodrome.com/societeculture/15505-menace-de-fievre-ebola-des-experts-proposent-une-operation-d-envergure-contreles-chauves-souris-du-plateau>.

Kosoy, M., Y. Bai, T. Lynch, I.V. Kuzmin, M. Niezgoda, R. Franka, B. Agwanda, R.F. Breiman, and C.E. Rupprecht. 2010. Bartonella spp. in bats, Kenya. Emerging Infectious Diseases 16:1875-1881.

Kunz, T. H., M. Betke, N. I. Hristov, and M. J. Vonhof. 2009. Methods for Assessing Colony Size, Population Size, and Relative Abundance of Bats. Pp. 133-157 in Ecological and Behavioral Methods for the Study of Bats (Kunz, T.H., and S. Parsons, eds.). 2nd edition. The Johns Hopkins University Press.

Kunz, T. H., E. Braun de Torrez, D. Bauer, T. Lobova, and T. H. Fleming. 2011. Ecosystem services provided by bats. Annals of the New York Academy of Sciences 1223:1-38.

LeE, J. 2014. "Ebola virus: What you need to know about the deadly outbreak". USA Today. <http://www. usatoday.com/story/news/nation-now/2014/07/28/ebola-virus-deadly-africa-outbreak/13260541/>

Leroy, E. M., P. Rouquet, P. Formenty, S. Souquière, A. Kilbourne, J. Froment, M. Bermejo, S. Smit, W. Karesh, R. Swanepoel, S. R. Zaki, and P. E. Rollin. 2004. Multiple Ebola virus transmission events and rapid decline of central African wildlife. Science 303(5656):387-390. 
Leroy, E. M., B. Kumulungui, X. Pourrut, P. Rouquet, A. Hassanin, P. Yaba, A. Délicat, J. T. Paweska, J. Gonzalez, AND R. Swanepoel. 2005. Fruit bats as reservoirs of Ebola virus. Nature 438:575-576.

Leroy, E. M., A. Epelboin, V. Mondonge, X. Pourrut, J Gonzalez, J. Muyembe-Tamfum, and P. Formenty. 2009. Human Ebola Outbreak Resulting from Direct Exposure to Fruit Bats in Luebo, Democratic Republic of Congo, 2007. Vector-borne and Zoonotic Diseases 9:723-728.

Leroy, E. M., I. Labouba, G. D. Maganga, and N. Berthet. 2014. Ebola in West Africa: The outbreak able to change many things. Clinical Microbiology and Infection doi:10.11:3-9.

LIDICKER, W. Z. 2010. The allee effect: Its history and future importance. The Open Ecology Journal 3:71-82.

Lloyd-Smith, J. O., P. C. Cross, C. J. Briggs, M. Daugherty, W. M. Getz, J. Latto, M. S. Sanchez, A. B. Smith, AND A. SwEl. 2005. Should we expect population thresholds for wildlife disease? Trends in Ecology and Evolution 20:12-15. doi:10.1016/j.tree.2005.07.004.

Luby, S. P., M. J. Hossain, E. S. Gurley, B. N. Ahmed, S. Banu, S. U. Khan, N. Homaira, P. A. Rota, P. E. Rollin, J. A. Comer, E. Kenah, T. G. Ksiazek, and M. Rahman. 2009. Recurrent zoonotic transmission of Nipah virus into humans, Bangladesh, 2001-2007. Emerging Infectious Diseases 15:1229-1235.

Luis, A. D., D. T. S. Hayman, T. J. O'Shea, P. M. Cryan, A. T. Gilbert, J. R. C. Pulliam, J. N. Mills, M. E. Timonin, C. K. R. Willis, A. A. Cunningham, A. R.Fooks, C. E. Rupprecht, J. L. N. Wood and C. T. Webb. 2013. A comparison of bats and rodents as reservoirs of zoonotic viruses: are bats special? Proceedings of the Royal Society B. 280(1756).

Maganga, G. D., M. Bourgarel, P. Vallo, T. D. Dallo, C. Ngoagouni, J. Felix Drexler, C. Drosten, E. R. Nakouné, E. M. Leroy, and S. Morand. 2014. Bat Distribution Size or Shape as Determinant of Viral Richness in African Bats. PLoS One 9:1-13.

Makin, D., AND H. Mendelssohn. 1985. Insectivorous bats victims of Israeli campaign. BATS 2:1-2.

Markus, N., AND L. Hall. 2004. Foraging behaviour of the black flying-fox (Pteropus alecto) in the urban landscape of Brisbane, Queensland. Wildlife Research 31:345-355.

Márquez, G. G. 1988. Love in the Time of Cholera. English translation. Random House LLC. New York, New York.

Martin, L., And A. P. Mclıwee. 2002. The reproductive biology and intrinsic capacity for increase of the Grey-headed Flying-fox Pteropus poliocephalus (megachiroptera) and the implications of culling. Pp 91-108 in Managing the Grey-headed Flying-fox as a threatened Species in New South Wales (Eby P., and D. Lunney, eds.). Mosman NSW: Royal Zoological Society of New South Wales, Australia.

Memish, Z. A., N. Mishra, K. J. Olival, S. F. Fagbo, V. Kapoor, J. H. Epstein, R. AlHakeem, A. Durosinloun, M. Al Asmari, A. Islam, A. Kapoor, T. Briese, P. Daszak, A. A. AlRabeeah, and W. I. Lipkin. 2013. Middle East respiratory syndrome coronavirus in bats, Saudi Arabia. Emerging Infectious Diseases 19:1819-1823.

Monadjem, A., P. J. Taylor, F. P. D. Cotterill, M. C. Schoeman. 2010a. Bats of Southern and Central Africa: A Biogeographic and Taxonomic Synthesis. Wits University Press. Johannesburg, South Africa.

Monadjem, A., M. C. Schoeman, A. Reside, D. V. Pio, S. Stoffberg, J. Bayliss, F. P. D. Cotterill, M. Curran, M. Kopp, P. J. TAYLoR. 2010b. A Recent Inventory of the Bats of Mozambique with Documentation of New Species for the Country. Acta Chiropterologica 12:371-391.

Morse, S. S. 1993. Emerging Viruses. Oxford University Press. New York, New York.

Mupapa, K., M. Massamba, K. Kibadi, K. Kuvula, A. Bwaka, M. Kipasa, R. Coleblunders, and J. J. MuyembeTamfum. 1999. Treatment of Ebola Hemorrhagic Fever with blood transfusions from convalescent patients. Journal of Infectious Diseases 179:18-23.

Odemwingie, E., And A. Tsan. 2014. "Ebola: Stakeholders Want Fruit Bat Population Reduced in Nigeria". Leadership (Nigeria). <http://leadership.ng/news/380810/ebola-stakeholders-want-fruit-batpopulation-reduced-nigeria>

Olival, K. J., And D. T. S. Hayman. 2014. Filoviruses in Bats: Current knowledge and future directions. Viruses 6:1759-1788. 
Parry-Jones, K. A., And M. L. Augee. 2001. Factors affecting the occupation of a colony site in Sydney, New South Wales by the grey-headed flying fox Pteropus poliocephalus (Pteropodidae). Austral Ecology 26:47-55.

Paweska, J. T., L. H. Blumberg, C. Liebenberg, R. H. Hewlett, A. A. Grobbelaar, P. A. Leman, J. E. Croft, L. H. Nel, L. Nutt, AND R. Swanepoel. 2006. Fatal Human Infection with Rabies-related Duvenhage Virus, South Africa. Emerging Infectious Diseases 12:1965-1967.

Plowright, R. K., P. Foley, H. E. Field, A. P. Dobson, J. E. Foley, P. Eby, and P. Daszak. 2011. Urban habituation, ecological connectivity and epidemic dampening: the emergence of Hendra virus from flying foxes (Pteropus spp). Proceedings of the Royal Society B 278(1725):3703-3712.

Pourrut, X., B. Kumulungul, T. Wittman, G. Moussavou, A. Délicat, P. Yaba, D. Nkoghe, J. Gonzalez, and E. M. LEROY. 2 005. The natural history of Ebola virus in Africa. Microbes and Infection 7:1005-1014.

Pourrut, X., A. Délicat, P. E. Rollin, T. G. Ksiazek, J. P. Gonzalez, and E. M. Leroy. 2007. Spatial and Temporal Patterns of Zaire ebolavirus and Antibody Prevalence in the Possible Reservoir Bat Species. Journal of Infectious Diseases 196:S176-S183.

Pourrut, X., M. Souris, J. S. Towner, P. E. Rollin, S. T. Nichol, J. Gonzalez, and E. Leroy. 2009. Large serological survey showing cocirculation of Ebola and Marburg viruses in Gabonese bat populations, and a high seroprevalence of both viruses in Rousettus aegyptiacus. BMC Infectious Diseases 9:159.

Puechmaille, S. J., P. Solsook, M. Yokubol, P. Piyapan, M. A. Gouilh, K. M. Mie, K. K. Kyaw, I. Mackie, S. Bumrungsri, A. Dejtaradol, T. Nwe, S. S. Hla Bu, C. Satasook, P. J. Bates, and E. C. Teeling. 2009. Population size, distribution, threats and conservation status of two endangered bat species Craseonycteris thonglongyai and Hipposideros turpis. Endangered Species Research 8:15-23.

RaceY, P. A. 2013. Bat Conservation: Past, Present, and Future. Pp. 517-532 in Bat Evolution, Ecology and Conservation (Adams, R. A., and S. C. Pedersen, eds.). Springer Science and Business Media. New York, New York.

REeD, Z. 2012. A historical perspective and review of the evidence to support fruit bats as the natural reservoir for Ebola viruses. Thesis, Georgia State University. http://scholarworks.gsu.edu/iph_theses/241.

RichteR, H. V. AND G. S. Cumming. 2008. First application of satellite telemetry to track African straw-coloured fruit bat migration. Journal of Zoology 275:172-176.

Schipper, J., J. S. Chanson, F. Chiozza, N. A. Cox, M. Hoffman, V. Katariya, J. Lamoreaux, A. S. L. Rodrigues, S. N. Stuart, H. J. Temple, J. Baillie, L. Boitani, T. E. Lacher Jr., R. A. Mittermeier, A. T. Smith, D. Absolon, J. M. Aguiar, G. Amori, N. Bakkour, R. Baldi, R. J. Berridge, J. Bielby, P. A> Black, J. J. Blanc, T. M. Brooks, J. A. Burton, T. M. Butynski, G. Catullo, R. Chapman, Z. Cokeliss, B. Collen, J. Conroy, J. G. Cooke, G. A. B. da Fonseca, A. E. Derocher, H. T. Dublin, J. W. Duckworth, L. Emmons, R. H. Emslie, M. Festa-Bianchet, M. Foster, S. Foster, D. L. Garshelis, C. Gates, M. Gimenez-Dixon, S. Gonzalez, J. F. Gonzalez-Maya, T. C. Good, G. Hammerson, P. S. Hammond, D. Happold, M. Happold, J. Hare, R. B. Harris, C. E. Hawkins, M. Haywood, L. R. Heaney, S. Hedges, K. M. Helgen, C. Hilton-Taylor, S. A. Hussain, N. Ishil, T. A. Jefferson, R. K. B. Jenlins, C. H. Johnston, M. Keith, J. Kingdon, D. H. Knox, K. M. Kovacs, P. Langhammer, K. Leus, R. Lewison, G. Lichtenstein, L. F. Lowry, Z. Macavoy, G. M. Mace, D. P. Mallon, M. Masi, M. W. McKnight, R. A. Medellín, P. Medicl, G. Mills, P. D. Moehlman, S. Molur, A. Mora, K. Nowell, J. F. Oates, W. Olech, W. R. L. Oliver, M. Oprea, B. D. Patterson, W. F. Perrin, B. A. Polidoro, C. Pollock, A. Powel, Y. Protas, P. Racey, J. Ragle, P. Ramani, G. Rathbun, R. R. Reeves, S. B. Reilly, J. E. Reynolds III, C Rondinini, R. G. Rosell-Ambal, M. Rulli, A. B. Rylands, S. Savini, C. J. Schank, W. Sechrest, C. Self-Sullivan, A. Shoemaker, C. Sillero-Zubiri, N. De Silva, D.E. Smith, C. Srinivasulu, P.J. Stephenson, N. van Strien, B. K. Talukdar, B. L. Taylor, R. Timmins, D. G. Tirira, M. F. Tognelli, K. Tsytsulina, L. M. Veiga, J. Vié, E. A. Williamson, S. A. Wyatt, and Y. Xie, B. E. Young. 2008. The status of the world's land and marine mammals: diversity, threat and knowledge. Science 322:225-230.

Shaffer, M. L. 1981. Minimum Population Sizes for Species Conservation. Bioscience 31:131-134.

Shaffer, M. L. 1983. Determining minimum viable population sizes for the grizzly bear. International Conference on Bear Research and Management 5:133-139. 
Shaffer, M. L., and F. B. Samson. 1985. Population size and extinction: a note on determining critical population sizes. American Naturalist 125:144-152.

Smithers, R. H. N. 1983. The Mammals of the Southern African Subregion. University of Pretoria Press. Pretoria, South Africa.

Smithers, R. H. N., AND J. L. P. LobÃo Tello. 1976. Check list and atlas of the mammals of Mozambique. Museum Memoir. The Trustees of the National Museums and Monuments of Rhodesia 8:1-184.

TAYLOR, P. J. 2000. Bats of Southern Africa. University of Natal Press. Pietermaritzburg, South Africa.

Tewksbury, J. J., J. G. T. Anderson, J. D. Bakker, T. J. Billo, P. W. Dunwiddie, M. J. Groom, S. E. Hampton, S. G. Herman, D. J. Levey, N. J. Machnickı, C. Martínez del Rio, M. E. Power, K. Rowell, A. K. Salomon, L. Stacey, S. C. Trombulak, and T. A. Wheeler. 2014. Natural History's Place in Science and Society. Bioscience doi:10.1093/biosci/biu032.

The Rainbow. 2014. "Ebola: FG targets fruit bats, healthcare wastes". The Nigerian voice.<http://www. thenigerianvoice.com/news/155677/50/ebola-fg-targets-fruit-bats-healthcare-wastes.html>

Traill, L. W., C. J. A. Bradshaw, And B. W. Brook. 2007. Minimum viable population size: a meta-analysis of 30 years of published estimates. Biological Conservation 139:159-166.

Turmelle, A. S., And K. J. Olival. 2009. Correlates of Viral Richness in Bats (Order Chiroptera). EcoHealth doi: 10.1007/s10393-009-0263-8.

United Nations (UN) Department of Economic and Social Affairs, Population Division. 2013. World Population Prospects: The 2012 Revision, Key Findings and Advance Tables. Working Paper No. ESA/P/WP.227. New York, EE.UU. <http://esa.un.org/wpp/documentation/pdf/WPP2012_\%20KEY\%20FINDINGS.pdf>

United Nations (UN) Office for Coordination of Humanitarian Affairs. IRIN Global. Ebola - softly, softly on bush meat. 1 August 2014. [Accessed 19 October 2014]. <http://www.irinnews.org/report/100428/ ebola-softly-softly-on-bush-meat>

Van Cakenberghe, V., and E. C. J. Seamark, eds. 2013. African Chiroptera Report 2013. African Chiroptera Project, Pretoria. <http://www.africanbats.org/Documents/ACR/2013/ACR_2013.pdf>.

Wolfe, N. D., P. Daszak, A. M. Kilpatrick, And D. S. Burke. 2005. Bushmeat hunting, deforestation, and prediction of zoonotic disease. Emerging Infectious Disease 11:1822-1827.

You, D., L. Hug, And D. Anthony. 2014. "Generation 2030: Africa". UNICEF Division of Data, Research and Policy. <http://www.unicef.org/publications/files/UNICEF_Africa_Generation_2030_en_11Aug. pdf>

Zinkina, J., AND A. Korotayev. 2014. Explosive population growth in tropical Africa: Crucial omission in development forecasts-emerging risks and way out. World Futures 70:120-139.

Summited: October 21, 2014

Review: December 8, 2014

Accepted:December10, 2014

Associated editor: William Lidicker 